DOI: $10.2478 / \operatorname{ctg}-2012-0011$

\title{
BULK GEOCHEMICAL DATA OF FOSSIL WOOD FROM THE MIDDLE JURASSIC CLAYS OF POLAND
}

\author{
Justyna Smolarek ${ }^{1}$ \\ ${ }^{1}$ Faculty of Earth Science, University of Silesia, Bedzinska Str. 60, 41-200 Sosnowiec. E-mail: justyna_smolarek@o2.pl
}

\begin{abstract}
Macroscopic observations, microscopic studies and literature data revealed that Middle Jurassic wood from Częstochowa area has a different state of preservation, and various types and degrees of mineralization and oxidation. Obtained results of organic matter fractionation illustrate a clear domination of polar fraction in the obtained extracts revealing low thermal maturity stage. Total organic carbon (TOC) values for analysed samples are in a wide range from $1.06 \%$ to $68.50 \%$. The highest amount of TOC were measured in not or poorly mineralized wood samples but most of them are mineralized wood fragments, showing the TOC values in the range of $2 \%-10 \%$. Percentage content of carbonate in fossil wood constitute in a wide range from less than $1 \% \mathrm{CaCO}_{3}$ to above $85 \% \mathrm{CaCO}_{3}$. The resulting percentage of the total sulfur content is very varied and do not show convergence with other data such as TOC, carbonate content, etc and is most probable connected with pyritisation range. Unlike the Middle Jurassic clay samples, where long-chain and short-chain $n$-alkanes occur in similar concentrations, in wood samples always short-chain $n$-alkanes dominated, in the range from 15 to 23 carbon atoms in molecule. The values of the CPI are generally higher than 1 which indicates the contribution of organic matter derived from higher plant waxes, which are characteristic of e.g. needles from gymnosperm plants. Under the influence of postdiagenetic oxidation in mineralized wood samples distribution of $n$-alkanes is changing. Diaster-13(17)-enes with 28 and 29 carbon atoms in molecule are present in the wood samples, while those with 29 atoms strongly prevail.
\end{abstract}

Keywords: fossil wood, Middle Jurassic, clays, organic matter, biomarkers, GC-MS

Reports according to the presence of fossil wood from the Middle Jurassic clays are known for many years (e.g., Jachowicz \& Dybova-Jachowicz 1994, see Jachowicz \& Dybova-Jachowicz 2003), but only recently this problem was studied in detail using paleobatanical and geochemical methods.

The mineralogical characteristics of fossil wood from Częstochowa region was made by Gut - Kałamaga (2000) in her master's thesis and it has demonstrated its phosphatic - carbonate mineralization.

Taxonomic research which was made by Philippe et al., (2006) has allowed to identify four genus of wood from that region, i.e.: Agathoxylon, Protopodocarpoxylon, Protaxodioxylon, Xenoxylon and a species Xenoxylon phyllocladoides GOTHAN.

Marynowski et al., (2007a, b; 2008) have carried out molecular research of wood from genus Protopodocarpoxylon ECKHOLD and Xenoxylon phyllocladoides GOTHAN, as well as taxonomic non-defined fragments of wood, showing the presence of such biomolecules as ferruginol, sugiol and other organic compounds including derivatives of the identified biomolecules.
What also interesting, above mentioned compounds are the oldest described biomolecules detected in a sedimentary organic matter $(\mathrm{OM})$ so far.

The aim of this work was to carry out a comprehensive bulk geochemical characteristic on numerous wood samples which has allowed to compare the contents of the organic fractions and their general molecular composition.

The study of content of total organic carbon (TOC) and total sulphur (TS) was made in order to demonstrate the differences between TOC values in respect of the degree of mineralization and the oxidation level. The thermal maturity of fossil wood was defined based on distribution of organic compounds.

\section{MATERIALS AND METHODS}

\section{MATERIALS}

Samples of Middle Jurassic wood occur in clays from the Polish Jura area. Wood samples come from active clay pits which are located in Czestochowa region: Gnaszyn Wienerberger, Sowa, Anna and near to that city between Grodzisko and Wreczyca Wielka (Grodzisko). 
Middle Jurassic wood from Czestochowa region is characterized by diverse state of preservation and the type and degree of mineralization (Gut - Kałamaga 2000).

Due to the degree of mineralization wood can be divided into:

not-mineralized wood fragments (xylite type) and gelified wood (jet type),

$>$ wood fragments partly mineralized,

$>$ wood fragments completely mineralized.

Due to the degree of oxidation the following wood types can be distinguished:

$>$ not-oxidized wood fragments,

$>$ partly oxidized wood fragments,

$>$ completely oxidized wood fragments.

\section{METHODS}

\section{Instrumental geochemical analysis}

\section{TOC}

The total organic carbon (TOC) and total sulfur (TS) contentwere determined using Eltra Elemental Analyser model CS530.

\section{Extraction and separation}

Samples were Soxhlet-extracted with dichloromethane (DCM) for $48 \mathrm{~h}$ in cellulose thimbles. Extracts were further separated using silica gel TLC plates (Merck, $20 \times 20 \times 0.25 \mathrm{~cm}$ ). Prior to separation, these plates were activated at $120^{\circ} \mathrm{C}$ for $1 \mathrm{~h}$. Plates were then loaded with the DCM and developed with $n$-hexane. Aliphatic, aromatic and polar fractions were eluted and separated with DCM. The aliphatic fractions of sample were further analysed in details by gas chromatography-mass spectrometry (GC-MS).

\section{GC-MS}

The GC-MS analyses were performed with an Agilent 6890 Series Gas Chromatograph interfaced to an Agilent 5973 Network Mass Selective Detector and Agilent 7683 Series Injector (Agilent Technologies, Palo Alto, CA).

The detailed description of GC-MS method was made by Marynowski \& Zatoń, (2010).

\section{RESULTS}

\section{Organic matter fractionation}

The test samples were separated into three organic fractions (aliphatic, aromatic, polar). Then, aliphatic fraction was analised using gas chromatography - mass spectrometry (GC-MS). Table 1 and triangular diagram (Fig.1) present the percentage distribution of each fraction content in tested wood samples.

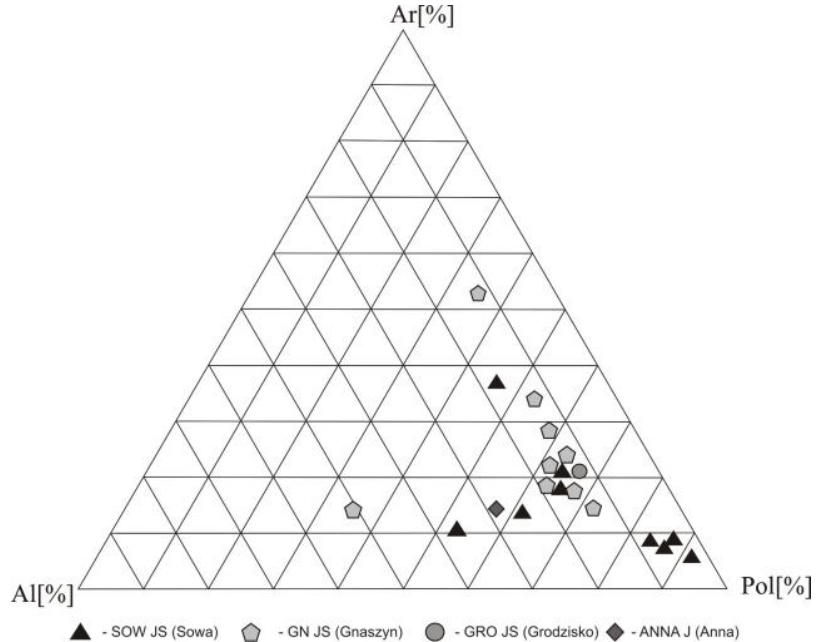

Fig. 1. Triangular diagram showing percentage content of aliphatic (Al), aromatic (Ar) and polar fraction (Pol) in investigated wood samples.

Table 1. Percentage content of total organic carbon (TOC) and carbonates, mass and percentage content of extract, content of extract per gram of organic carbon (EOM) and percentage content of aliphatic (Al), aromatic (Ar) and polar fraction (Pol) in wood samples.

\begin{tabular}{|c|c|c|c|c|c|c|c|c|}
\hline \multirow{2}{*}{ Sample } & \multirow{2}{*}{$\begin{array}{l}\text { TOC } \\
{[\%]}\end{array}$} & \multirow{2}{*}{$\begin{array}{c}\text { Carbonate } \\
{[\%]}\end{array}$} & \multirow{2}{*}{$\begin{array}{c}\text { Extract } \\
\text { mass [g] }\end{array}$} & \multirow{2}{*}{$\begin{array}{c}\% \\
\text { extract } \\
\text { content }\end{array}$} & \multirow{2}{*}{$\begin{array}{c}\mathrm{EOM} \\
\mathrm{mg} / \mathrm{gTOC}\end{array}$} & \multicolumn{3}{|c|}{ Fractions } \\
\hline & & & & & & $\begin{array}{c}\text { Al } \\
{[\%]}\end{array}$ & $\begin{array}{c}\mathrm{Ar} \\
{[\%]}\end{array}$ & $\begin{array}{l}\text { Pol } \\
{[\%]}\end{array}$ \\
\hline \multicolumn{9}{|c|}{ Sowa } \\
\hline $\begin{array}{c}\text { SOW } \\
\text { JS1 }\end{array}$ & 3.65 & 21.49 & 0.0306 & 0.0582 & 15.93 & 25 & 13 & 62 \\
\hline $\begin{array}{c}\text { SOW } \\
\text { JS2 }\end{array}$ & 4.65 & 28.98 & 0.0397 & 0.0726 & 15.60 & 17 & 23 & 60 \\
\hline $\begin{array}{c}\text { SOW } \\
\text { JS3 }\end{array}$ & 5.68 & 41.34 & 0.0841 & 0.1430 & 25.17 & 1 & 8 & 91 \\
\hline $\begin{array}{c}\text { SOW } \\
\text { JS4 }\end{array}$ & 5.87 & 9.00 & 0.0665 & 0.1120 & 19.08 & 2 & 5 & 93 \\
\hline $\begin{array}{c}\text { SOW } \\
\text { JS6 }\end{array}$ & 4.01 & 30.62 & 0.2328 & 0.4635 & 115.66 & 37 & 10 & 53 \\
\hline $\begin{array}{c}\text { SOW } \\
\text { JS7 }\end{array}$ & 2.23 & 44.85 & 0.0226 & 0.0479 & 21.49 & 19 & 36 & 45 \\
\hline $\begin{array}{c}\text { SOW } \\
\text { JS9 }\end{array}$ & 3.47 & 38.72 & 0.0466 & 0.0921 & 26.53 & 9 & 6 & 85 \\
\hline $\begin{array}{c}\text { SOW } \\
\text { J10 }\end{array}$ & 6.47 & 35.45 & 0.3149 & 0.6285 & 97.17 & 17 & 19 & 64 \\
\hline $\begin{array}{c}\text { SOW } \\
\text { J13 }\end{array}$ & 3.95 & 41.68 & 0.1134 & 0.2243 & 56.76 & 3 & 9 & 88 \\
\hline $\begin{array}{c}\text { SOW } \\
\text { J14 }\end{array}$ & 8.36 & 10.16 & 0.0623 & 0.1384 & 16.56 & - & - & - \\
\hline \multicolumn{9}{|c|}{ Gnaszyn } \\
\hline GN JS2 & 7.49 & 12.05 & 0.0629 & 0.1324 & 17.68 & 13 & 16 & 71 \\
\hline GN JS4 & 9.14 & 9.63 & 0.0677 & 0.1651 & 18.06 & 18 & 18 & 64 \\
\hline GN JS5 & 68.5 & - & 0.3250 & 1.7857 & 26.07 & 14 & 22 & 64 \\
\hline GN JS6 & 2.21 & 66.71 & 0.0410 & 0.0784 & 35.45 & 13 & 28 & 59 \\
\hline $\begin{array}{l}\text { GNU } \\
\text { SR }\end{array}$ & 2.01 & 85.74 & 0.0295 & 0.0587 & 29.26 & 17 & 18 & 65 \\
\hline $\begin{array}{l}\text { GNU } \\
\text { SP }\end{array}$ & 1.28 & 76.12 & 0.0123 & 0.0273 & 21.25 & 11 & 53 & 36 \\
\hline $\begin{array}{l}\text { GNU } \\
\text { UT }\end{array}$ & 1.06 & 57.38 & 0.0108 & 0.0238 & 22.44 & 50 & 14 & 36 \\
\hline $\begin{array}{c}\text { GN } \\
\text { W20 }\end{array}$ & 41.60 & 0.37 & 0.0015 & 0.0033 & 0.08 & 12 & 35 & 53 \\
\hline GN & 2.87 & 73.63 & 0.0205 & 0.0391 & 13.64 & 16 & 22 & 62 \\
\hline \multicolumn{9}{|c|}{ Grodzisko } \\
\hline $\begin{array}{l}\text { GRO } \\
\text { JS1 }\end{array}$ & 10.45 & 42.53 & 0.0948 & 0.1806 & 17.29 & 13 & 20 & 67 \\
\hline $\begin{array}{l}\text { GRO } \\
\text { JS4 }\end{array}$ & 4.27 & 41.81 & 0.0107 & 0.0222 & 5.20 & - & - & - \\
\hline \multicolumn{9}{|c|}{ Anna } \\
\hline$\underset{\text { J1 }}{\text { ANNA }}$ & 2.25 & 68.10 & 0.2328 & 0.4637 & 206.01 & 29 & 14 & 57 \\
\hline
\end{tabular}




\section{Total organic carbon (TOC)}

TOC values in the test samples are in wide interval from $1.06 \%$ to $68.50 \%$. The largest amount of TOC have been found in non-mineralized or partly mineralized wood samples (GNW20, GNJS5; Fig.2).

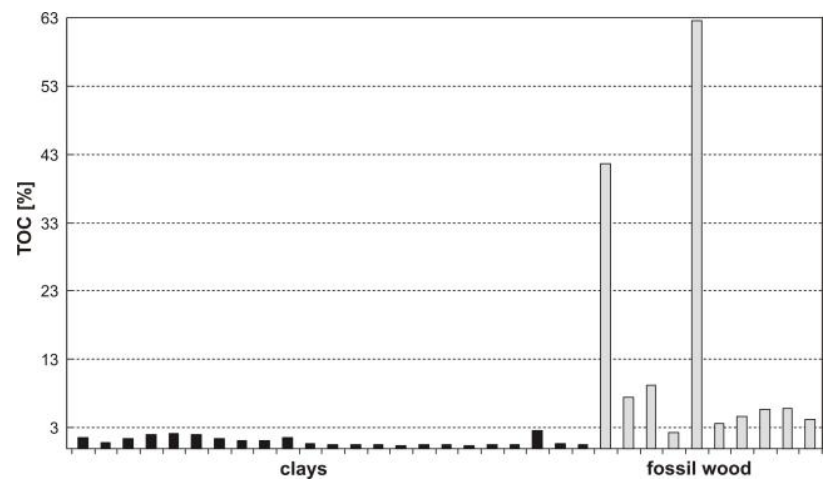

Fig. 2. A comparison of percentage content of the TOC for Middle Jurassic clays (from Marynowski et al. 2007a) and fossil wood tested in this work, indicating higher values for notoxidized wood samples.

These two samples representing only the outer, carbonized part of wood (GNW20) or are rare, small pieces of non-mineralized wood with a poorly preserved structure (GNJS5). For comparison, sample GNW20S with TOC $=2.87 \%$ is the internal, mineralized part of the GNW20 wood fragment (Tab.1).

\section{Carbonate content}

Carbonate content is in the wide range of almost $1 \% \mathrm{CaCO}_{3}$ to $85 \% \mathrm{CaCO}_{3}$. What interesting, these samples which are poor in carbonates are in some cases characterized by low amounts of TOC. It would indicate the presence of other than the carbonate mineral phases from which most likely are phosphates and sulfides (pyrite, marcasite and sphalerite)

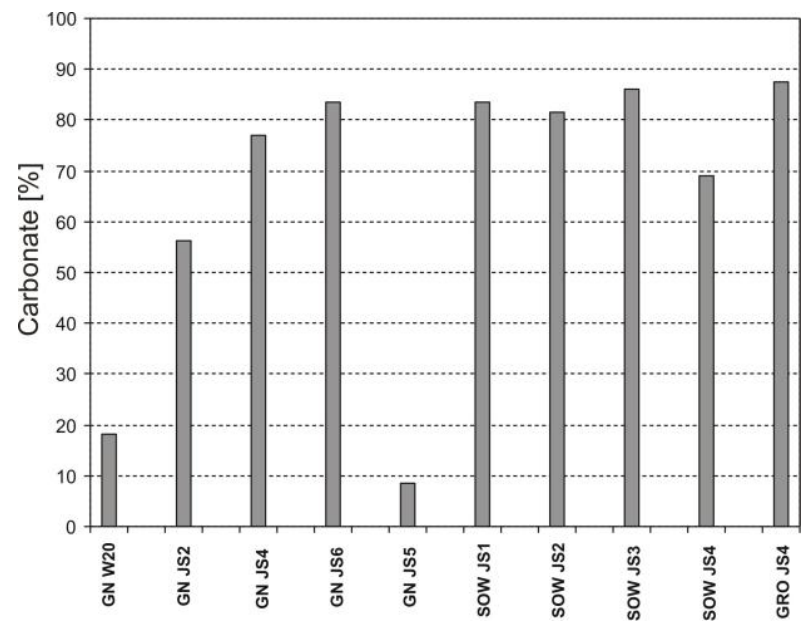

Fig. 3. Percentage content of carbonates in choosen nonoxidized wood samples.

\section{Total sulphur (TS)}

For some part of samples the content of total sulphur was determined (Fig.4). Obtained percentage values of total sulphur are very varied and do not show convergence with any other data (e.g, TOC, contents of carbonates). It suggests other than organic origin of sulphur in analysed fossil wood, what raises a presumption that its main sources are sulphides, especially pyrite and marcasite.

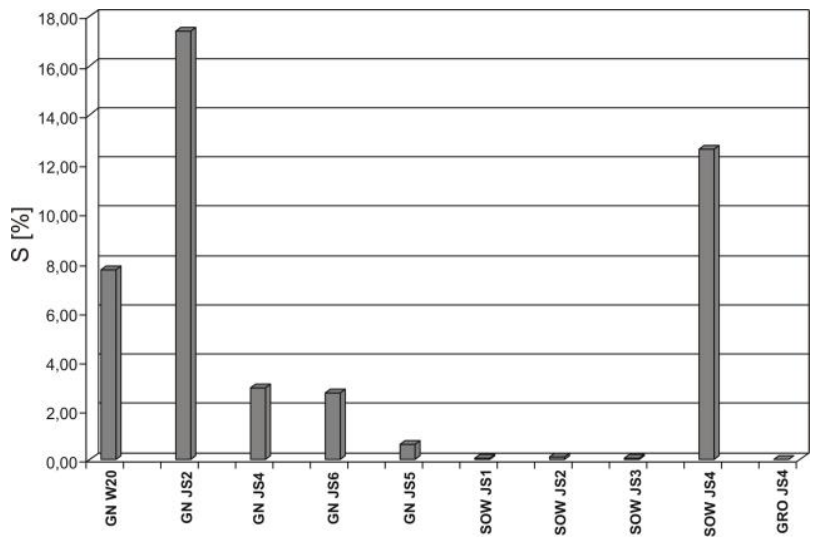

Fig. 4. A comparison of percentage content of total sulphur from selected samples of Middle Jurassic wood, analyzed using ELTRA CS 530.

\section{n-Alkanes, isoprenoids}

$N$-alkanes are hydrocarbons which characterized by a linear arrangement of carbon atoms in the structure. The most often, structure of $n$-alkanes is dependent on source of organic matter. Generally, short-chain $n$-alkanes (from $\mathrm{C}_{12}$ to $\mathrm{C}_{23}$ ) are characteristic for algae's lipid fraction, some bacteria, as well as cyanobacteria. Moreover, these alkanes are characteristic components of trees trunks. In case of long-chain $n$-alkanes (from $\mathrm{C}_{25}$ to $\mathrm{C}_{33}$ ) they are the derivatives of fatty acids present in waxes of higher plants. Therefore, the preponderance of long-chain alkanes over short-chain is usually characteristic for epicontinental sediments, rocks of terrestrial origin, as well as deltaic (Peters \& Moldowan 1993), that means for facies rich in organic matter comes from higher plants.

There was elaborated row of indicators based on distributions of $n$ - alkanes and isoprenoids. It has allowed to define organic matter parameters. Two parameters, present in sediments: pristane $(\mathrm{Pr})$ and phytane $(\mathrm{Ph})$ were used for this work. Isoprenoids are hydrocarbon compounds from polymerized isoprene units. Pristane and phytane are the branched acyclic hydrocarbons which have 19 and 20 carbon atoms in molecule (Peters \& Moldowan 1993).

Unlike the Middle Jurassic clay samples, where long-chain and short-chain $n$-alkanes occur in similar concentrations (Marynowski et al. 2007a), in wood samples always outweigh short-chain $n$-alkanes present in the range from 15 to 23 carbon atoms in molecule (Table 2, Table 3). In general, the dominant $n$-alkanes are $\mathrm{C}_{17}, \mathrm{C}_{18}$ 
or $\mathrm{C}_{19}$ (Table 2, Fig 5), although in some samples there was an advantage of $\mathrm{C}_{23} n$-alkane (Table 3 ).

Table 2. Summary of indicators from $n$-alkanes and isoprenoids group.

\begin{tabular}{|c|c|c|c|c|c|c|}
\hline Sample & CPI & $\begin{array}{l}\text { CPI } \\
(25- \\
31)\end{array}$ & $\mathrm{Pr} / \mathrm{Ph}$ & $\begin{array}{l}\mathrm{Pr} / n- \\
\mathrm{C} 17\end{array}$ & $\begin{array}{l}\mathrm{Ph} / n- \\
\mathrm{C} 18\end{array}$ & $\begin{array}{c}(n \mathrm{C} 17+\mathrm{nC} 18+\mathrm{nC} 19) \\
(n \mathrm{C} 27+\mathrm{nC} 28+\mathrm{nC} 29)\end{array}$ \\
\hline $\begin{array}{l}\text { Sow } \\
\text { JS1 }\end{array}$ & 2.20 & 1.49 & 0.70 & $\begin{array}{r}\text { Sowa } \\
0.53\end{array}$ & 0.61 & 5.05 \\
\hline $\begin{array}{l}\text { SOW } \\
\text { JS2 }\end{array}$ & 1.70 & 1.42 & 0.60 & 0.65 & 0.62 & 3.71 \\
\hline $\begin{array}{l}\text { SOW } \\
\text { JS3 }\end{array}$ & 1.76 & 2.30 & 0.49 & 0.64 & 0.70 & 4.01 \\
\hline $\begin{array}{l}\text { SOW } \\
\text { JS4 }\end{array}$ & 1.29 & 1.57 & 0.60 & 0.78 & 0.69 & 3.09 \\
\hline $\begin{array}{l}\text { SOW } \\
\text { JS6 }\end{array}$ & 2.28 & 2.48 & 0.79 & 0.82 & 0.88 & 19.19 \\
\hline $\begin{array}{l}\text { SOW } \\
\text { JS7 }\end{array}$ & 1.81 & 1.55 & 0.79 & 0.85 & 0.81 & 10.93 \\
\hline $\begin{array}{l}\text { SOW } \\
\text { JS9 }\end{array}$ & 1.66 & 1.76 & 0.51 & 0.73 & 0.79 & 7.82 \\
\hline $\begin{array}{l}\text { SOW } \\
\text { JS10 }\end{array}$ & 1.51 & 1.84 & 0.47 & 0.67 & 0.68 & 5.17 \\
\hline $\begin{array}{l}\text { Sow } \\
\text { JS13 }\end{array}$ & 1.29 & 1.09 & 0.55 & 0.69 & 0.79 & 1.63 \\
\hline \multicolumn{7}{|c|}{ Gnaszyn } \\
\hline GN JS2 & 3.73 & 1.89 & 0.89 & 0.92 & 0.71 & 3.63 \\
\hline GN JS4 & 1.42 & 1.23 & 0.98 & 1.17 & 0.78 & 2.98 \\
\hline GN JS5 & 0.98 & 0.98 & 0.37 & 1.55 & 1.39 & 1.85 \\
\hline GN JS6 & 2.30 & 1.41 & 0.48 & 0.99 & 0.83 & 2.57 \\
\hline GNU SR & 1.58 & 1.38 & 0.70 & 0.75 & 0.71 & 3.85 \\
\hline GNU UT & 1.78 & 1.97 & 0.62 & 0.94 & 1.08 & 52.58 \\
\hline GN W20 & 2.47 & - & 0.69 & 0.72 & 0.90 & - \\
\hline $\begin{array}{c}\text { GN } \\
\text { W20S }\end{array}$ & 1.94 & 1.99 & 0.73 & 0.67 & 0.84 & 50.88 \\
\hline \multicolumn{7}{|c|}{ Grodzisko } \\
\hline $\begin{array}{l}\text { GRO } \\
\text { JS1 }\end{array}$ & 1.53 & 1.18 & 0.89 & 0.86 & 0.70 & 2.51 \\
\hline \multicolumn{7}{|c|}{ Anna } \\
\hline $\begin{array}{c}\text { ANNA } \\
\text { J1 }\end{array}$ & 1.87 & 1.36 & 0.94 & 0.92 & 0.88 & 9.81 \\
\hline
\end{tabular}

Explanations to table 2:

$\operatorname{Pr} / n \mathbf{C}_{17}$-pristane to $n$-heptadekane ratio (Peters \& Moldowan 1993)

$\mathbf{P h} / \boldsymbol{n} \mathbf{C}_{18}$ - phytan to $n$-oktadekane ratio (Peters \& Moldowan 1993)

CPI - Carbon Preference Index

$\mathrm{CPI}_{(25-31)}=\frac{\left(\mathrm{C}_{25}+\mathrm{C}_{27}+\mathrm{C}_{29}\right)+\left(\mathrm{C}_{27}+\mathrm{C}_{29}+\mathrm{C}_{31}\right)}{\left[2\left(\mathrm{C}_{26}+\mathrm{C}_{28}+\mathrm{C}_{30}\right)\right]}$

(Kotarba et.al. 1994)
$C P I_{(\text {Total })}=\frac{\left(C_{17}+C_{19} \ldots+C_{27}+C_{29}\right)+\left(C_{19}+C_{21} \ldots+C_{29}+C_{31}\right)}{\left[2\left(C_{18}+C_{20} \ldots+C_{28}+C_{30}\right)\right]}$

(Kotarba et.al. 1994)

$\mathbf{P r} / \mathbf{P h}$ - pristane to phytane ratio

(Peters \& Moldowan 1993)

$\left(n \mathrm{C}_{17}+n \mathrm{C}_{18}+n \mathrm{C}_{19}\right) /\left(n \mathrm{C}_{27}+n \mathrm{C}_{28}+n \mathrm{C}_{29}\right)$ - ratio of short-chain $n$ alkanes with 17, 18 and 19 carbon atoms in the molecule to long-chain $n$-alkanes with 28 and 29 carbon atoms in the molecule.

However, the values of the CPI (Table 2) are generally higher than 1 (an except for the sample GN JS5), which indicates the contribution of organic matter derived from higher plant waxes, which are characteristic of needles from gymnosperm plants, as well as leaves and epithelia etc. angiosperms ( Peters et al., 2005).

In case of analyzed samples the prevalence of longchain odd-over-even $n$-alkanes (Fig. 5) may resulting either from partial contamination of wood surrounding by clays, or the presence of a small amount of waxes in the tissues of wood, or the presence of both factors described above.

\section{Diasterenes}

Diaster-13(17)-enes which have 28 and 29 carbon atoms in molecule are present in the investigated samples, with preponderance of that with 29 atoms in the molecule (Tab. 4, Fig. 6; Fig. 7). Only in few wood samples the occurrence of diaster-13(17)-enes with 27 carbon atoms in the molecule have been detected, always in low concentration.

In distinction from wood samples, clays are characterized by presence of diaster-13(17)-enes which have 27 carbon atoms (Fig. 7). Moreover, diaster-13(17)-enes which have 30 carbon atomes are present in clays but its concentrations is quite low (Marynowski et al. 2007a). The presence of diaster-13(17)-enes with 27 carbon atoms in some wood samples suggests their contamination by clays.

\section{DISCUSSION}

\section{Organic matter fractionation}

The high concentrations of polar fraction is characteristic for organic matter of low thermal maturity (Tissot \&Welte 1984). On the other hand, high content of aliphatic fraction may suggest the contribution of organic material typical of higher plants (cuticle waxes, etc.). Low content of aromatic fractions may be related to the oxidation of organic matter, resulting in formation of polar compounds like quinones or ketones (Wilkes et al. 1998).

The results of fractionation show a clear advantage of polar fraction in the tested extracts. Similarly, the high content of polar fraction was obtained in the work Marynowski et al. (2007a). Molecular investigation and vitrinite reflectance measurements have showed that the organic matter present in investigated fossil wood is at a 
very low stage of thermal transformation as indicated by: the presence of biomolecules (Marynowski et al. 2007 a and $b$ ) and the vitrinite reflectance of about $0.3 \%$ (Marynowski et al. 2007b). Samples which were an exception and containing a relatively high amounts of aromatic or aliphatic fraction are oxidized wood fragments from Gnaszyn. It follows that the oxidation processes of organic matter of terrestrial origin cause the percentage changes of organic fraction consisting of the increase in content of aromatic and aliphatic fractions for the polar fraction.

\section{Total organic carbon (TOC)}

Total organic carbon (TOC) is normally used to determine the organic carbon content in the samples of sedimentary rocks (Tissot \& Welte 1984).

Previous studies indicate a general upward trend of total organic carbon content, extending with an increase in anoxic conditions in the water column during sedimentation of organic matter (eg, Demaison \& Moore 1980).

However, Calvert et al. (1996) are proving that high content of organic carbon may also be formed under anoxic conditions of sedimentation, and the main factor determining its amount in sediment is called organic productivity (the high activity of microorganisms - especially the algae).

Most of the samples demonstrate TOC values in the range of $2 \%-10 \%$ (Table 1 , Fig 2). These values are consistent with the values obtained for seven wood samples from the location Kawodrza, Blanowice, Żarki, Anna, Gnaszyn (Marynowski et al. 2007a). These authors have obtained TOC values in the range of $7 \%-14 \%$ for mineralized and partly mineralized wood and $30 \%-40 \%$ for poorly mineralized wood.

\section{n-Alkanes, isoprenoids}

Pristane to phytane ratio $(\mathrm{Pr} / \mathrm{Ph})$ is mainly used to reconstruct the sedimentary conditions of organic matter (Didyk et al. 1978). The wood values of this ratio is less than 1 (Table 2), what may suggest rather reductive conditions prevailing in the basin.

However, due to the specific nature of the samples, which are pieces of wood representing a fairly uniform type of organic matter, the above described ratio does not reflect the conditions during sedimentation of the investigated samples.

The indicators $\mathrm{Ph} / n-\mathrm{C} 18$ and $\mathrm{Pr} / n-\mathrm{C} 17$ are usually less than 1 , indicating a higher content of $n$-alkanes relative to isoprenoids in wood samples. In two cases (GNJS4, GNJS5) slightly higher values may be related to its partial biodegradation. During the biodegradation process short-chain $n$-alkanes are removed at the first stage (Connan 1984).

An interesting aspect is to compare the distribution of $n$-alkanes in one sample of wood, with oxidized zone, however it is difficult to determine whether it is diagenetic oxidation, or - more likely - post-diagenetic oxidation resulting from weathering.
Oxidized zone (GNUSR) is characterized by the dominant of $n$-alkanes $\mathrm{C}_{18}$ and $\mathrm{C}_{19}$, as well as the occurrence of relatively high concentrations of $n$-alkanes $\mathrm{C}_{22}$ and $\mathrm{C}_{23}$ and also the relatively intensive $n$-alkanes ranging from $\mathrm{C}_{26}$ to $\mathrm{C}_{33}$.

Besides, in the sample GNUSR the predominance of long-chain odd-over-even $n$-alkanes $\left(\mathrm{C}_{27}, \mathrm{C}_{29}, \mathrm{C}_{31}, \mathrm{C}_{33}\right)$ over even $n$-alkanes $\left(\mathrm{C}_{26}, \mathrm{C}_{28}, \mathrm{C}_{30}, \mathrm{C}_{32}\right)$ was observed. The transition zone and the oxidized zone in samples have a very similar distribution of $n$-alkanes, where dominated short-chain $n$-alkanes and long-chain $n$-alkanes are present in very small quantities. This is particularly visible in the oxidized sample. The oxidation of organic matter, during which a reduction of long-chain $n$-alkanes occur is known from literature data with respect to weathering (oxidation) of clays (Elie et al. 2000), as well as the lower- and upper Triassic clays from southern Poland (Marynowski \& Wyszomirski 2008). However oxidation processes could be strongly connected with organic matter biodegradation.

\section{Diasterenes}

Steroids occurring in the sedimentary organic matter have formed from sterols and stanols, biosynthesized by living organisms through the transformation taking place at an early stage of organic matter burial.

Steranes and diasteranes - the final products of diagenetic transformations of sterols and stanols - are common compounds, described in the coals, crude oils and other sedimentary rocks. Steranes usually contain from 27 to 29 carbon atoms in the structure, although in specific sedimentary environments also steranes with 21, 22, 26 and 30 carbon atoms in the molecule can be present.

The formation of diaster-13(17)-enes is possible only when the organic matter "neighbors" with clay minerals during diagenesis. It causes the rearrangement of carbon skeleton and the formation of diaster-13(17)-enes and in much lower concentrations spirosterenes.

During the subsequent diagenetic transformation processes (mainly by affecting the temperature ingeological time), from diasterenes arise diasteranes, commonly found in sedimentary organic matter (Peakman et al. 1987). Diasterenes are precursors of common in sedimentary organic matter, diasteranes and are found in thermally immature samples (Rubinstein et al. 1975).

According to literature data (Brassell et al. 1985) $\mathrm{C}_{29}$-diaster-13(17)-enes come from higher plants, while $\mathrm{C}_{27}$-diaster-13(17)-enes are from marine organic matter, mainly algae. In Middle Jurassic clays both marine and terrestrial diasterenes occur and these second are dominated (Marynowski et al. 2007a). However in fossil wood almost only C29- diaster-13(17)-enes are present, while other diasterenes are contamination of wood samples by clays (Figs. $5 \& 6$, Table 4). 
Table 3. Proportional content of $n$-alkanes counted based on surface area of the peaks.

\begin{tabular}{|c|c|c|c|c|c|c|c|c|c|c|c|c|c|c|c|c|c|c|c|}
\hline Sample & $\begin{array}{l}\text { Cl5 } \\
\text { [\%] }\end{array}$ & $\begin{array}{l}\text { Cl6 } \\
{[\%]}\end{array}$ & $\begin{array}{l}\mathrm{Cl7} \\
{[\%]}\end{array}$ & $\begin{array}{l}\text { C18 } \\
{[\because[]}\end{array}$ & $\begin{array}{l}\text { C19 } \\
{[\%]}\end{array}$ & $\begin{array}{l}\mathrm{C} 20 \\
{[\%]}\end{array}$ & $\begin{array}{l}\mathrm{C} 2 \mathrm{l} \\
[\%]]\end{array}$ & $\begin{array}{l}\mathrm{C} 22 \\
{[\%]}\end{array}$ & $\begin{array}{c}\mathrm{C} 23 \\
\text { [\%] } \\
\text { Sowa }\end{array}$ & $\begin{array}{l}\mathrm{C} 24 \\
{[\%]}\end{array}$ & $\begin{array}{l}\mathrm{C} 25 \\
{[\%]}\end{array}$ & $\begin{array}{l}\mathrm{C} 26 \\
{[\%]}\end{array}$ & $\begin{array}{l}\mathrm{C} 27 \\
\text { [\%] }\end{array}$ & $\begin{array}{l}\mathrm{C28} \\
{[\mathrm{[} \%]}\end{array}$ & $\begin{array}{l}\text { C29 } \\
\text { [\%] }\end{array}$ & $\begin{array}{l}\mathrm{C} 30 \\
\text { [\%] }\end{array}$ & $\begin{array}{l}\text { C31 } \\
\text { [\%] }\end{array}$ & $\begin{array}{l}\mathrm{C} 32 \\
{[\%]}\end{array}$ & $\begin{array}{l}\mathrm{C} 33 \\
\text { [\%] }\end{array}$ \\
\hline SOWJS1 & 0.5 & 2.7 & 8.8 & 10.8 & 9.5 & 7.1 & 14.7 & 8.0 & 17.1 & 5.3 & 5.4 & 2.7 & 2.6 & 1.5 & 1.6 & 0.7 & 0.9 & 0.0 & 0.0 \\
\hline SOWJS2 & 0.0 & 1.2 & 5.6 & 9.9 & 9.3 & 7.6 & 13.3 & 9.8 & 14.7 & 7.3 & 7.4 & 4.0 & 2.9 & 1.7 & 2.1 & 1.2 & 2.2 & 0.0 & 0.0 \\
\hline SOWJS3 & 0.0 & 1.3 & 4.3 & 8.0 & 10.0 & 10.2 & 11.5 & 12.9 & 20.7 & 4.8 & 5.6 & 2.0 & 1.9 & 1.1 & 2.6 & 0.7 & 2.5 & 0.0 & 0.0 \\
\hline SOWJS4 & 0.0 & 1.3 & 6.6 & 12.3 & 12.8 & 9.5 & 8.9 & 12.9 & 6.2 & 4.6 & 3.6 & 3.2 & 3.4 & 2.5 & 4.3 & 1.7 & 4.0 & 1.0 & 1.2 \\
\hline SOWJS6 & 0.0 & 9.3 & 13.3 & 15.6 & 13.5 & 9.9 & 10.5 & 6.6 & 11.3 & 2.7 & 3.0 & 0.8 & 0.9 & 0.4 & 1.0 & 0.4 & 1.0 & 0.0 & 0.0 \\
\hline SOWJST & 4.7 & 7.5 & 13.0 & 17.2 & 12.7 & 8.5 & 9.5 & 7.1 & 6.1 & 3.7 & 2.5 & 1.8 & 1.7 & 0.8 & 1.4 & 0.5 & 1.1 & 0.0 & 0.0 \\
\hline SOWJS9 & 0.0 & 2.0 & 12.0 & 22.0 & 15.0 & 10.6 & 7.7 & 7.2 & 5.2 & 3.6 & 2.2 & 1.7 & 2.4 & 1.3 & 2.5 & 1.3 & 3.1 & 0.0 & 0.0 \\
\hline SOWJS10 & 0.0 & 1.1 & 9.2 & 19.7 & 15.8 & 11.5 & 8.8 & 9.3 & 5.6 & 4.4 & 3.0 & 2.4 & 1.7 & 3.2 & 1.1 & 3.3 & 0.0 & 0.0 & 0.0 \\
\hline SOWJS13 & 0.0 & 1.5 & 7.8 & 12.4 & 9.0 & 6.1 & 5.1 & 5.9 & 6.0 & 6.9 & 7.2 & 7.9 & 7.2 & 5.6 & 5.1 & 2.7 & 3.5 & 0.0 & 0.0 \\
\hline \multicolumn{20}{|c|}{ Gnaszyn } \\
\hline GN JS2 & 0.0 & 1.0 & 3.7 & 5.4 & 6.0 & 4.3 & 14.7 & 5.0 & 31.0 & 4.1 & 14.4 & 1.5 & 2.0 & 1.0 & 1.2 & 3.3 & 1.5 & 0.0 & 0.0 \\
\hline GN JS4 & 0.0 & 2.3 & 6.9 & 10.6 & 12.1 & 9.0 & 8.7 & 7.7 & 5.8 & 4.7 & 4.6 & 3.7 & 4.2 & 3.0 & 4.9 & 8.3 & 3.5 & 0.0 & 0.0 \\
\hline GN JS5 & 0.0 & 0.7 & 2.6 & 7.9 & 6.8 & 7.4 & 8.7 & 14.0 & 10.3 & 11.1 & 9.2 & 7.7 & 4.2 & 2.9 & 2.3 & 2.0 & 2.4 & 0.0 & 0.0 \\
\hline GIV JSO & 0.0 & 0.6 & 3.6 & 8.8 & 9.1 & 7.3 & 11.3 & 8.6 & 26.9 & 3.7 & 4.6 & 2.1 & 2.7 & 1.8 & 3.8 & 3.1 & 1.8 & 0.0 & 0.0 \\
\hline GNU SR & 0.0 & 3.0 & 8.6 & 12.9 & 10.6 & 7.9 & 7.9 & 8.9 & 11.8 & 5.9 & 5.2 & 3.2 & 3.2 & 2.3 & 2.9 & 1.6 & 2.2 & 1.0 & 0.9 \\
\hline GNU UT & 0.0 & 5.8 & 12.7 & 18.0 & 17.4 & 13.8 & 11.0 & 7.6 & 7.4 & 2.7 & 1.7 & 0.6 & 0.4 & 0.2 & 0.3 & 0.1 & 0.3 & 0.0 & 0.0 \\
\hline GN W20 & 0.0 & 9.3 & 18.0 & 21.3 & 14.0 & 10.1 & 13.3 & 5.4 & 5.1 & 1.9 & 1.6 & 0.0 & 0.0 & 0.0 & 0.0 & 0.0 & 0.0 & 0.0 & 0.0 \\
\hline GN W20S & 0.0 & 9.9 & 16.6 & 18.2 & 14.2 & 10.3 & 10.3 & 78 & 6.5 & 2.6 & 1.7 & 0.9 & 1.0 & 0.0 & 0.0 & 0.0 & 0.0 & 0.0 & 0.0 \\
\hline \multicolumn{20}{|c|}{ Grodzisko } \\
\hline GRO JSI & 0.0 & 2.0 & 10.3 & 14.1 & 10.4 & 7.0 & 6.1 & 6.2 & 6.8 & 5.2 & 8.4 & 3.7 & 8.8 & 3.0 & 2.0 & 6.0 & 0.0 & 0.0 & 0.0 \\
\hline \multicolumn{20}{|c|}{ Anna } \\
\hline ANNA Jl & 0.0 & 11.6 & 15.9 & 17.6 & 11.3 & 8.2 & 8.8 & 5.7 & 4.6 & 3.1 & 2.8 & 2.0 & 1.8 & 1.3 & 1.5 & 0.9 & 2.0 & 0.9 & 0.0 \\
\hline
\end{tabular}

Table 4. Proportional participation of diaster-13(17)-enes from 27 to 29 carbon atoms in molecules.

\begin{tabular}{|cccc|}
\hline Sa mple & $\begin{array}{c}27(\mathrm{~S}+\mathrm{R}) \\
{[\%]}\end{array}$ & $\begin{array}{c}28(\mathrm{~S}+\mathrm{R}) \\
{[\%]}\end{array}$ & $\begin{array}{c}29(\mathrm{~S}+\mathrm{R}) \\
{[\%]}\end{array}$ \\
\hline \multicolumn{5}{c}{ Sow a } \\
SOW JS1 & 0.0 & 8.1 & 91.9 \\
SOW JS2 & 0.0 & 4.9 & 95.1 \\
SOW JS3 & 2.8 & 5.5 & 91.7 \\
SOW JS4 & 0.0 & 9.3 & 90.7 \\
SOW JS6 & 0.0 & 6.9 & 93.1 \\
& G na szyn & \\
GN J S2 & 1.2 & 3.9 & 94.8 \\
GN JS4 & 2.4 & 11.1 & 86.5 \\
GN JS5 & 0.0 & 21.2 & 78.8 \\
GN J S6 & 0.8 & 3.4 & 95.8 \\
GNU SR & 0.0 & 12.3 & 87.7 \\
GNU UT & 0.0 & 4.7 & 95.3 \\
GN W20 & 0.0 & 5.8 & 94.2 \\
GN W20S & 0.0 & 7.5 & 92.5 \\
& A nn a & \\
ANNA J1 & 0.0 & 2.4 & 97.6 \\
\hline
\end{tabular}




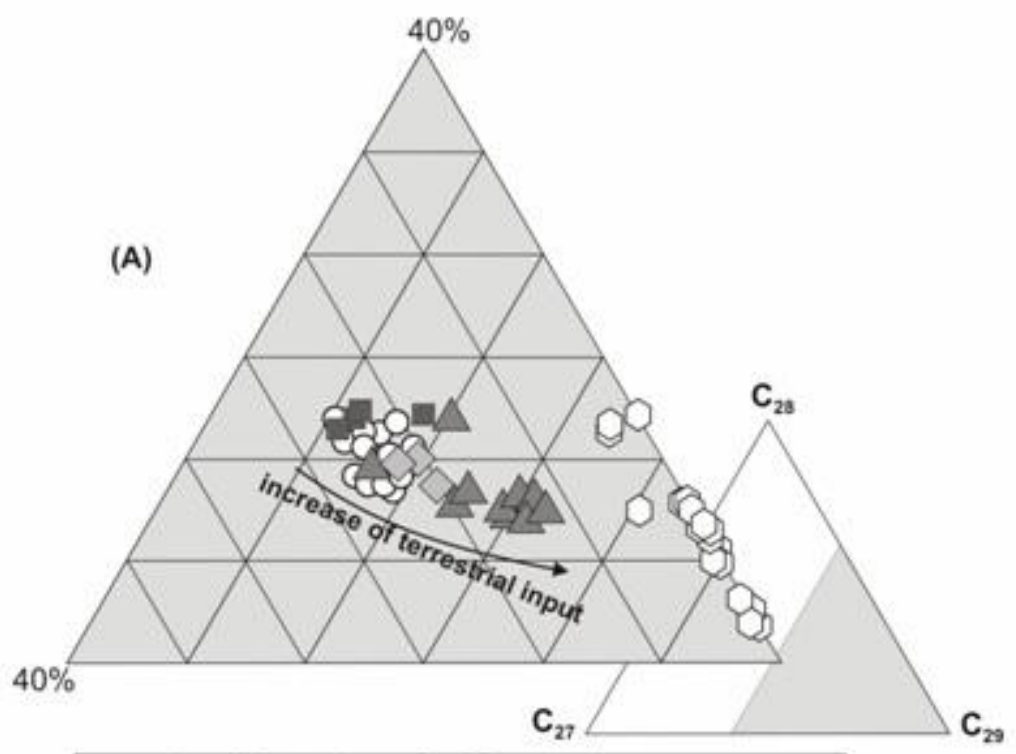

- - clays (Częstochowa Clay Formation)

- - carbonate concretions (Częstochowa Clay Formation)

- - wood (Częstochowa Clay Formation)

$\diamond$ - clays (Holy Cross Mountains)

A - clays (Polish Lowland) for Marynowski et.al., 2007b

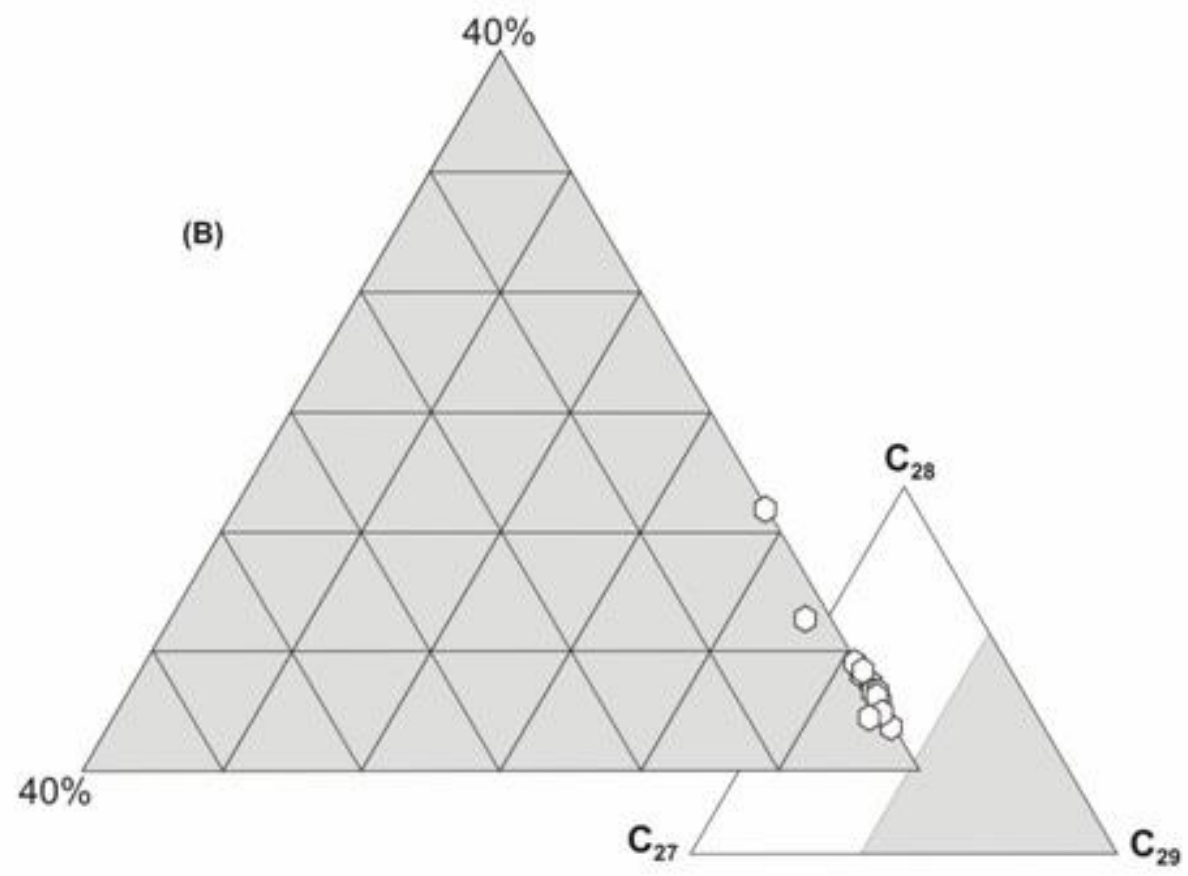

Fig. 5. Comparision of proportional content of diasterenes in (a) clays, wood and carbonate concretions from Marynowski et al. (2007a) and (b) in fossil wood analysis from this work. 
$m / z 257$
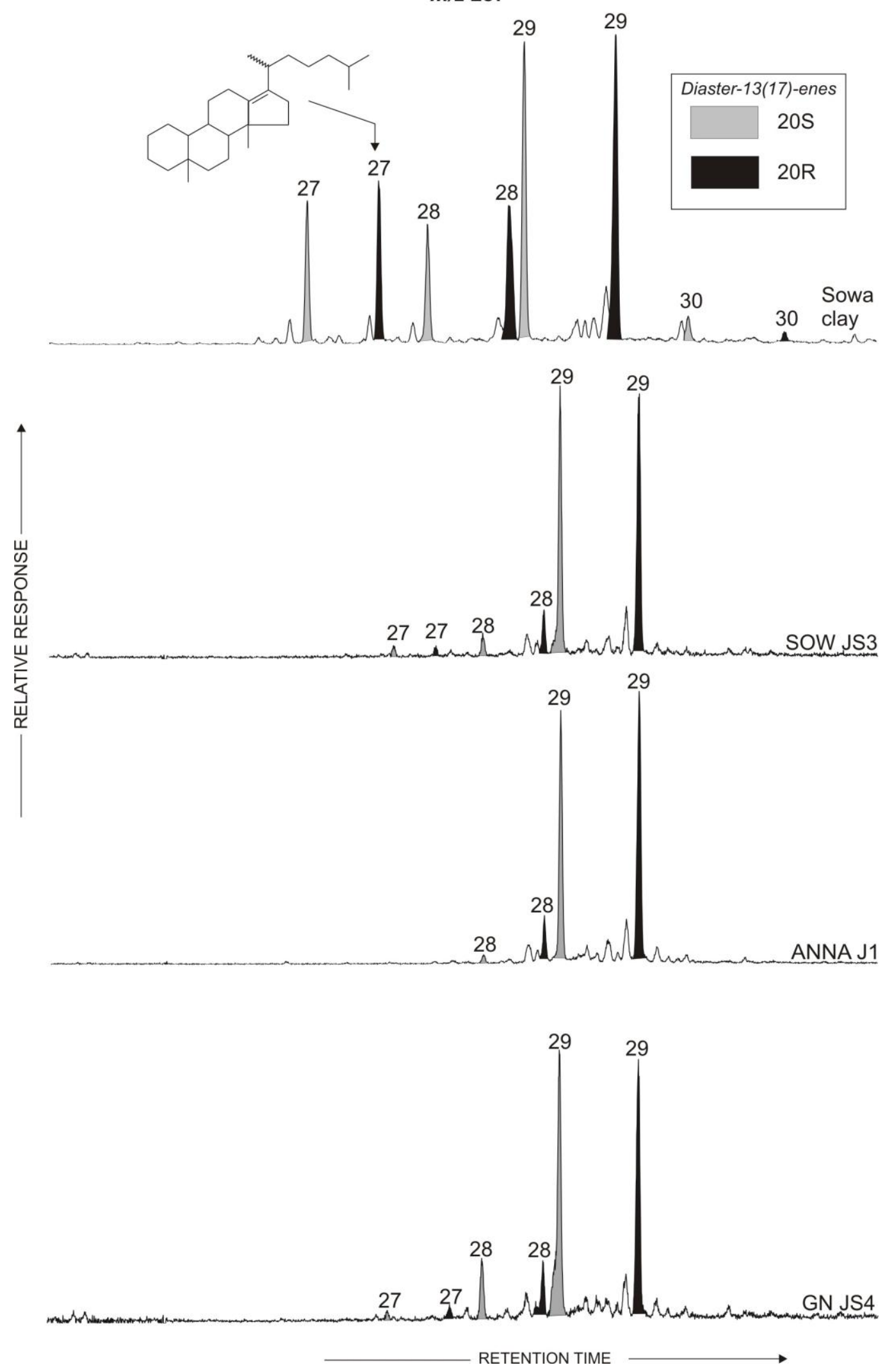

Fig. 6. Examples of diaster-13(17)-enes distribution characteristic for the Middle Jurassic deposits including clay sample (from Marynowski et. al., 2007a) as well as wood samples from clay pit Sowa, Anna and Gnaszyn. Shortcuts explanations in Table 1. 


\section{CONCLUSIONS}

* Macroscopic observations, microscopic studies and literature data revealed that Middle Jurassic wood from Częstochowa area has a different state of preservation, and various types and degrees of mineralization and oxidation.

* Obtained results of organic matter fractionation illustrate a clear domination of polar fraction in the investigated extracts. Dominant content of polar fraction are characteristic of the samples in the low thermal maturity stage. Oxidized wood fragments from Gnaszyn - GNUSP and GNUUT are an exception and contain a relatively high amounts of aromatic and aliphatic fraction. Oxidation (weathering) of organic matter of terrestrial origin changing the percentage consisting of organic fraction, it means growing content of aromatic and aliphatic fraction instead of polar fraction.

* TOC values in tested samples are in a wide range from $1.06 \%$ to $68.50 \%$. The greatest amount of total organic carbon were in the non-mineralized or poorly mineralized wood. Most of the samples are mineralized wood fragments, showing the TOC values in the range of $2 \%-10 \%$.

* Percentage content of carbonate in experienced wood samples constitute in a wide range from less than $1 \% \mathrm{CaCO}_{3}$, to above $85 \% \mathrm{CaCO}_{3}$. An exception are poorly mineralized samples where carbonate content ranges from $50 \%-90 \%$.

* The percentage of the total sulfur content is very varied for wood samples and do not show convergence with other data such as TOC, carbonate content, etc.

* Unlike the Middle Jurassic clay samples, where long-chain and short-chain $n$-alkanes occur in similar concentrations in wood samples always shortchain $n$-alkanes from 15 to 23 carbon atoms in molecule dominating.

* The values of the CPI are generally higher than 1 which indicates the contribution of organic matter derived from higher plant waxes, which are characteristic of needles from gymnosperm plants. In case of analyzed samples the prevalence of longchain $n$-alkanes odd-over-even may result either from partial contamination of wood surrounding by clays, or the presence of a small amount of waxes in the tissues of wood, possibly is also the presence of both factors described above.

* Under the influence of post-diagenetic oxidation in mineralized wood samples distribution of $n$-alkanes is changing.

* In tested wood samples are diaster-13(17)-enes with 28 and 29 carbon atoms in molecule, while those with 29 atoms strongly prevail. Diaster-13(17)-enes are present only in part of the wood samples, what may result from the impact of diagenetic processes on the presence or absence of these compounds in wood samples.

\section{REFERENCES}

Brassell S.C., Eglinton G., Mo, F. J. (1985) Biological marker compounds as indicators of the depositional history of the Maoming oil shale. Organic Geochemistry 10, 927-941

Calvert S. E., Bustin R. M. (1996) Ingall Influence of water column anoxia and sediment supply on the burial and preservation of organic carbon in marine shales. Geochimica et Cosmochimica Acta 60, 1577-1593.

Connan J. (1984) Biodegradation of crude oils in reservoirs. In: Brooks J., Welte D. (Eds.). Advances in Petroleum Geochemistry, vol. 1. Academic Press, London, pp. 299-335.

Demaison, G.J. and Moore, G.T. (1980) Anoxic environments and oil source bed genesis. Am. Assoc. Pet. Geol. Bull. 64, 1179-1209.

Didyk B.M., Simoneit B.R.T., Brassell S.C., Eglinton G. (1978) Organic geochemical indicators of palaeoenvironmental conditions of sedimentation. Nature 272, 216-222.

Elie, M., Faure, P., Michels, R., Landais, P., Griffault, L. (2000) Natural and laboratory oxidation of low-organic-carboncontent sediments: comparison of chemical changes in hydrocarbons. Energy \& Fuels 14, 854-861.

Gut-Kałamaga M. (2000) Mineralizacja drewna Jury środkowej z rejonu Częstochowy. Praca magisterska. Archiwum Uniwersytetu Śląskiego, Sosnowiec (in Polish).

Jachowicz J., Dybova - Jachowicz S. (2003) Paleobotanika. Wydawnictwo Uniwersytetu Śląskiego, Katowice, $1-210$ (in Polish).

Kotarba M., Kowalski A., Więcław D. (1994) Nowa metoda obliczeń wskaźnika CPI i wykorzystanie dystrybucji nalkanów i izoprenoidów prospekcji naftowej - instrukcja metodyczna analiz z zakresu geochemii organicznej dla potrzeb poszukiwań naftowych. Materiały wewnętrzne AGH: 82-91 (in Polish).

Marynowski L., Zatoń M., Simoneit B.R.T., Otto A., Jędrysek M.O., Grelowski C., Kurkiewicz S. (2007a) Compositions, sources and depositional environments of organic matter from the Middle Jurassic clays of Poland. Applied Geochemistry 22, 2456-2485.

Marynowski L., Otto A., Zatoń M., Philippe M., Simoneit B.R.T. (2007b) Biomolecules preserved in 168 million year old fossil conifer wood. Naturwissenschaften 94, 228-236.

Marynowski L., Wyszomirski P. (2008) Organic geochemical evidences of early diagenetic oxidation of the terrestrial organic matter during the Triassic arid and semi arid climatic conditions. Applied Geochemistry 23, 2612-2618

Marynowski L., Philippe M., Zatoń M., Hautevelle Y. (2008) Systematic relationships of the Mesozoic wood genus Xenoxylon: an integrative biomolecular and palaeobotanical approach. N. Jb. Geol. Paläont. Abd. 247, 177-189.

Marynowski L., Zatoń M. (2010) Organic matter from the Callovian (Middle Jurassic) deposits of Lithuania: Compositions, sources and depositional environments. Applied Geochemistry 25, 933-946.

Peakman J., Torren M., Maxwell J. R. (1987) Early diagenetic pathways of steroids alkanes. Adwances in Organic Geochemistry 13, 583-592.

Peters K.E., Moldowan J.M. (1993) The biomarkers guide. Interpreting molecular Fossils in Petroleum and Ancient Sediments: 363p. Prentice Hall, Englewood Cliffs, New Jersey.

Philippe M., Barbacka M., Gradinaru E., Iamendei E., Iamandei S., Kázmér M., Popa M., Szakmány G., Tchoumatchenco P., Zatoń M. (2006) Fossil wood and Mid-Eastern Europe 
terrestrial palaeobiogeography during the Jurassic-Early Cretaceous interval. Review of Palaeobotany and Palynology 142, 15-32.

Rubinstein I., Sieskind O., Albrecht P. (1975) Rearranged sterenes in a shale: Occurrence and simulated formation. Journal of the Chemical Society; Perkin Transactions I, 1833-1836.

Tissot B., Welte D. H. (1984) Petroleum Formation and Occurence-Springer-Verlag, New York, s.699.

Wilkes H., Disco U., Horsfield B. (1998) Aromatic aldehydes and ketones in the Posidonia shale, Hils syncline, Germany. Organic Geochemistry 29, 107-117.

\begin{abstract}
Abstrakt
Makroskopowe obserwacje, mikroskopowe badania i dane literaturowe wykazały, że środkowojurajskie drewno z okolic Częstochowy ma różny stan zachowania oraz różne rodzaje i stopień mineralizacji oraz utlenienia. Uzyskane wyniki rozdziału frakcyjnego pokazują wyraźną przewagę frakcji polarnej w badanych ekstraktach. Wartości TOC dla badanych próbek wahają się w szerokim zakresie od $1,06 \%$ do $68,50 \%$. Największa ilość TOC występuje w nie zmineralizowanych lub słabo zmineralizowanych próbkach drewna. Większość próbek to zmineralizowane fragmenty drewna, pokazując wartości TOC w zakresie od $2 \%-10 \%$. Zawartość procentowa węglanów w badanych próbkach znajduje się w szerokim zakresie od mniej niż $1 \% \mathrm{CaCO}_{3}$ do ponad $85 \% \mathrm{CaCO}_{3}$. Procentowa zawartość siarki całkowitej jest bardzo zróżnicowana i nie wykazuje zbieżności z innymi danymi, takimi jak TOC czy zawartość węglanów, itp. W odróżnieniu od środkowojurajskich iłów, gdzie długołańcuchowe i krótkołańcuchowe $n$-alkany występują w podobnych stężeniach , w próbkach drewna zawsze przewyższają nalkanów krótkołańcuchowe, występujące w zakresie od 15 do 23 atomów węgla w cząsteczce. Wartości wskaźnika CPI są generalnie wyższe niż 1 , co wskazuje na udział materii organicznej pochodzącej z wosków roślin wyższych. Pod wpływem post-diagenetycznego utleniania zmineralizowanych próbek drewna zmienia się dystrybucja $n$-alkanów. W badanych próbkach obecne są diaster-13 (17)-enes o 28 i 29 atomów węgla w cząsteczce, natomiast te o 29 atomów znacznie przeważają.
\end{abstract}

Słowa kluczowe: skamieniałe drewno, jura środkowa, iły, materia organiczna, biomarkery, GC-MS 